\title{
PRODUCTIVE PERFORMANCE OF NEW ZEALAND WHITE GROWING RABBITS FED ON DIETS CONTAINING DIFFERENT LEVELS OF TREATED CASTOR MEAL
}

\author{
Marwa A. Suliman; Walaa A. Salama; R.I.M. Matari and M.A. El-Shora \\ Animal Production Research Institute, Agricultural Research Center, Dokki, Giza, Egypt.
}

SUMMARY

\begin{abstract}
$\mathrm{T}$ The aim of this study was to evaluate the effect of replacing two levels (20 or $40 \%)$ of chemically or biologically treated castor meal (CTCM or BTCM) of the control diet soybean meal on growing rabbits performance. One hundred New Zealand White rabbits, six weeks old with an average live body weight ranging from 733 to $777 \mathrm{~g}$ were randomly divided into five groups and each group was divided into 5 replicated (4 rabbits/replicate). The growing period lasted 8 weeks. Diets were offered ad-libtium and fresh water was available all times. Results indicated that chemical and biological treatments were somewhat affect chemical composition in which mainly CP content was markedly increased but CF was decreased by biological treatment. Nutrients digestibility data indicated that insignificant differences among dietary treatments in respect of DM and OM digestibilities. Digestibility of CF, EE, NFE and CP were significantly decreased by using diet containing 40\% BTCM in comparison with control. The values of DCP and TDN were significant lower with 40\% BTCM diet than those of control one, while the other tested diets mostly didn't differ significantly than control regarding these parameters. Nitrogen balance values were insignificant decreased for diets containing CTCM and BTCM at levels 20 and 40\% compared with control diet. Final body weight and body weight gain values were insignificant decreased for rabbits fed all diets except for those fed on $40 \%$ BTCM diet that they values were decreased significantly compared with those of control one. Feed intake recorded the lowest value with rabbits fed 20\% CTCM diet, while the highest value was occurred with those fed on $40 \%$ CTCM diet. Based on control diet most tested diets didn't affect significantly feed intake. The best FCR was occurred with 20\% CTCM sit, while worst one was associated with 40\% CTCM diet and difference among most treatments non-significant. There were no significant differences among treatments regarding the most blood constituents and all values were in the normal range. Diets contained CTCM or BTCM at 20\% level were achieved the highest economic efficiency followed by control diet or 40\% BTCM diet and the least one was associated with 40\% CTCM diet. Generally, it could be recommended to use the CTCM or BTCM in growing rabbit's diets at $20 \%$ instead of soybean meal without any adverse effects on their growth performance and health condition.
\end{abstract}

Keywords: Castor meal, chemically treatment, biologically treatment, rabbits performance, digestibility and blood constituents.

\section{INTRODUCTION}

The castor oil plant (Ricinuscommunis L.) is a member of the spurge family of plants (Euphorbiaceae). Castor beans have been found in ancient Egyptians tombs dating back to 4000 B.C. According to the Ebers papyrus an Egyptian medical text from 1500 B.C., Egyptian doctors used castor oil for protect the eyes from irritation and body ointments (Long, 2005). Castor bean plant is highly toxic because of the presence of ricin, a water soluble glycoprotein concentrated in the seed endosperm but present in lower amounts in the rest of the plant and reputed to be one of the most poisonous of the naturally occurring compounds. Mainly it is grown commercially for the oil in seed, which is used primarily for industrial purposes and in the manufacture of cosmetics. Most of the world's product of castor oil with the annual production of 1,854,775 ton in the year 2013 (FAO, 2013). Castor bean meal is the main by-product of castor oil production. Pressing one ton of castor beans for oil extraction produces around $550 \mathrm{~kg}$ of cake, but this value can vary with seed oil content and oil extraction process according to Severino (2005). Castor meal can be used as fertilizer, fungicide, in plant-parasitic nematode control and animal feed. Castor meal is a product with high protein content (28-43\%) but because of the presence of ricin and lectinin, castor bean meal is seldom used as a livestock feed (Aganga and Tshwenyane, 2003). Mechanism of ricin inhibit protein synthesis but other mechanisms are noted including apoptosis pathway, direct cell membrane damage, alteration of membrane structure and function and release of 


\section{Suliman et al.}

cytokine inflammatory mandatories (Day et al., 2002). Lectin which unlike ricin have affinity for the blood cell. The ricin concentration in castor meal was $1.14-3.7 \mathrm{mg} / \mathrm{kg}$ DM (Diniz et al., 2010). There are several methods like as physical, chemical and biological treatments are essential for detoxification of toxic material from castor meal and to improve their nutritive value. Autoclaving at pressure 15 psi for $60 \mathrm{~min}$. and lime treatment (calcium oxide, $40 \mathrm{~g} / \mathrm{kg}$ ) completely removed ricin from castor meal (Anandan et al., 2005). Biological treatment used to reduce ricin by using certain fungi, such as Penicillium simplicissimum that reducing ricin by $16 \%$ (Godoy et al., 2009).

Therefore, the objective of the present study was to investigate the effect of two replacement levels of soybean meal by treated chemically (Calcium oxide) and biologically (Penicillium funiculusms) castor meal on rabbits growth performance, digestibility, some blood parameter and economical profit.

\section{MATERIALS AND METHODS}

The experimental work of this study was carried out at Kafr EL-Sheikh station belonging to Animal Production Research Institute, Agricultural Research Center, Ministry of Agriculture, Egypt. The microbiological and chemical treatments were conducted at the Laboratories of By-Products Research Department, Animal Production Research Institute, Giza, Egypt.

\section{Processing of castor meal:}

Castor meal was obtained from El captain Company, Cairo, Egypt. It was ground by hammer mill and stored in an air-tight condition and kept for subsequent processing.

\section{Biological treatment:}

Fungal strain Penicillium funiculusms F-116 was obtained from Microbial Chemistry Department, National Research Center, Dokki, Egypt. The microorganisms were preserved on Potato Dextrose Agar (PDA) medium at $25^{\circ} \mathrm{C}$ until used. About $50 \mathrm{~g}$ of castor meal was weighted and packed in heat resistant bags $(10 \times 20 \mathrm{~cm})$ and sterilized by autoclaving at $121{ }^{\circ} \mathrm{C}$ for 30 minutes. Spore suspension of Penicillium funiculusms was prepared and used to inoculate $500 \mathrm{ml}$ capacity conical flasks containing $20 \mathrm{~g}$ of cooled sterilized residue, moistened by basal medium containing (g/ L) $4 \%$ molasses, $0.4 \%$ urea, $0.2 \% \mathrm{KH}_{2} \mathrm{PO}_{4}$ and $0.03 \% \mathrm{MgSO}_{4} .7 \mathrm{H}_{2} \mathrm{O}$ and incubated for 7 days. The treated castor meal was moistened at $65-70 \%$ and put specific fungal spawn and left for three weeks.

\section{Chemical treatment:}

Castor meal was treated using calcium oxide solution, with each $\mathrm{kg}$ diluted in 10 liters of water and applied at $60 \mathrm{~g}$ of $\mathrm{CaO}$ per $\mathrm{kg}$ of castor meal as recommended by Oliveira et al. (2007). After mixing the meal with the $\mathrm{CaO}$ solution, the material rested for twelve hours (one night) and was then drained in a cemented area. The drying time, being varied according to the weather condition and was approximately $48 \mathrm{~h}$.

\section{Animal's management and feeding:}

One hundred weaned New Zealand White (NZW) rabbits, six weeks old with live body weight ranging from 733.00 to $776.67 \mathrm{~g}$ were allotted to five dietary treatments of twenty rabbits per treatment. Each treatment was replicate five times and each replicate had four rabbits. All rabbits were kept under the same managerial and hygienic conditions and housed in metal battery cages supplied with separated feeders. Diets were offered $a d-$ libtium and fresh water was available all times from automatic nipple drinkers. All rabbits were vaccinated against diseases and kept under veterinary control.

Five experimental diets were formulated, including the control diet without castor meal while, the other tested diets have chemically or biologically treated castor meal at 20 or $40 \%$ replacement of soybean meal (2.82 or $5.64 \%$ in basal diet). The ingredients of diets formulation and its chemical composition are presented in Table (1). All the experimental diets were formulated to be isonitrogenous and isocaloric, to meet all the essential nutrient requirements of growing rabbits (NRC, 1977).

\section{Experimental parameters:}

\section{Growth performance:}

Feed intake (FI, g/ rabbit/ day) and body weight gain (BWG, g/ rabbit/ day) were recorded weekly, while feed conversion was calculated accordingly as $\mathrm{g}$ feed / $\mathrm{g}$ gain over an experimental period of 8 weeks.

\section{Digestion trial:}


At the end of experimental feeding trial period (14 weeks of age), digestibility trials were carried out using 25 NZW males (5 from each treatment) to determine the nutrients digestion coefficients and nutritive value of experimental diets. A plastic net was placed under the cages to retain feces during the collection period (4 days), feces were collected daily before the morning meal and weighed fresh and dried at $60^{\circ} \mathrm{C}$ for $24 \mathrm{hrs}$ in an air drying oven. Feces were sampled then ground and mixed, stored for subsequent chemical analysis. Data of quantities and chemical analysis of feed and feces were used to calculate the nutrient digestion coefficients and nutritive value for each dietary treatment, as described by Fekete (1985).

Table (1). Ingredients and chemical composition of experimental diets (on DM basis).

\begin{tabular}{|c|c|c|c|c|c|}
\hline \multirow{2}{*}{ Ingredients } & \multirow{2}{*}{ Control diet } & \multicolumn{2}{|l|}{ CTCM } & \multicolumn{2}{|c|}{ BTCM } \\
\hline & & $20 \%$ & $40 \%$ & $20 \%$ & $40 \%$ \\
\hline Soybean meal (44\% CP) & 14.10 & 11.28 & 8.46 & 11.28 & 8.46 \\
\hline Castor bean meal & -- & 2.82 & 5.64 & 2.82 & 5.64 \\
\hline Barley & 29.00 & 31.00 & 32.00 & 31.00 & 32.00 \\
\hline Wheat bran & 15.00 & 15.00 & 16.50 & 15.00 & 16.50 \\
\hline Clover hay & 35.15 & 33.15 & 30.65 & 33.15 & 30.65 \\
\hline Lime stone & 0.70 & 0.70 & 0.70 & 0.70 & 0.70 \\
\hline Calcium carbonate $\left(\mathrm{CaCO}_{3}\right)$ & 2.20 & 2.20 & 2.20 & 2.20 & 2.20 \\
\hline Sodium chloride $(\mathrm{NaCl})$ & 0.30 & 0.30 & 0.30 & 0.30 & 0.30 \\
\hline Vit.\& min. $\operatorname{mix}^{1 *}$ & 0.30 & 0.30 & 0.30 & 0.30 & 0.30 \\
\hline DL-Methionine & 0.20 & 0.20 & 0.20 & 0.20 & 0.20 \\
\hline Anticoccidia(Diclazuril) & 0.05 & 0.05 & 0.05 & 0.05 & 0.05 \\
\hline Molasses & 3.00 & 3.00 & 3.00 & 3.00 & 3.00 \\
\hline Total & 100 & 100 & 100 & 100 & 100 \\
\hline \multicolumn{6}{|l|}{ Chemical analysis (\%) } \\
\hline $\mathrm{DM}$ & 89.40 & 90.06 & 90.17 & 89.76 & 90.26 \\
\hline $\mathrm{OM}$ & 90.34 & 88.66 & 88.32 & 89.77 & 89.58 \\
\hline $\mathrm{CP}$ & 16.73 & 16.48 & 16.38 & 16.68 & 16.65 \\
\hline $\mathrm{CF}$ & 13.12 & 13.34 & 13.45 & 13.20 & 13.20 \\
\hline $\mathrm{EE}$ & 2.50 & 2.63 & 2.53 & 2.67 & 2.06 \\
\hline NFE & 57.99 & 56.21 & 55.96 & 57.22 & 57.67 \\
\hline Ash & 9.66 & 11.34 & 11.68 & 10.23 & 10.42 \\
\hline DE kcal/ kg** & 2520.35 & 2513.27 & 2509.73 & 2517.78 & $\begin{array}{c}2517.7 \\
8\end{array}$ \\
\hline
\end{tabular}

CTCM: Chemically treated castor meal.

BTCM: Biologically treated castor meal.

*Each $\mathrm{kg}$ of vitamins and minerals mixture contains: Vit. A 2.000.000 IU, Vit.B 1 0.33g, Vit.B $1.0 \mathrm{~g}$, Vit.D 150.000

$I U$, Vit E 8.33g, Vit. K 0.33 g, Pantothenic acid 3.33g; Nicotinic acid, 30.00g; Vit. B6 2.00g; Vit. B12 1.7 mg, Folic acid 0.83g, Biotin $33 \mathrm{mg}, \mathrm{Cu} 0.5 \mathrm{~g}$, choline chloride 200mg, Mn 5.0g, Fe 12.5g, Mg 66.7mg, Co $1.33 \mathrm{mg}$, Se 16.6 $\mathrm{mg}, \mathrm{Zn} 11.7 \mathrm{~g}$,Iodine $16.6 \mathrm{mg}$ and Antioxidant 10.0g.

$* * D E(k c a l / k g)=4.36-0.049 \times[28.924+0.657(C F \%)]$ according to Cheeke, (1987).

\section{Chemical analyses:}

Samples of castor meal, diets and feces were prepared to determine of moisture, ash, nitrogen, ether extract and crude fiber according to A.O.A.C. (2000).

\section{Blood parameters:}

Blood samples were taken from the five previous rabbits within each treatment at the time of slaughter test and were collected into dry clean centrifuge tubes containing drops of heparin and centrifuged at 3000 r.p.m for 20 minutes then plasma were transferred and stored in deep freezer at approximately $-20^{\circ} \mathrm{C}$ till the time of chemical analysis. Chemical analyses of the blood plasma were carried out for quantitative determination of blood total lipids (Zollner and Kirsch, 1962), cholesterol (Richmond, 1973), creatinine (Schirmeister, 1964), urea (Fawcett and Scott, 1960), total protein (Gorrnall et al., 1949), albumin (Doumas and Waston 1971), transaminase (AST, aspartate aminotransferase and ALT alanine aminotransferase, Young, 1990). All biochemical analyses of blood samples were determined by using spectrophotometer. 


\section{Statistical analysis:}

The experimental data were analyzed using general linear model using ANOVA procedures of SAS (2004) by the following model:

$Y_{i j}=\mu+T_{i}+e_{i j}$.

Where:

$\mathrm{Y}_{\mathrm{ij}}=$ the observation of the parameter measured.

$\mu=$ Overall mean of Yij.

$\mathrm{T}_{\mathrm{i}}=$ Effect of dietary treatment, $\mathrm{i}=(1 \ldots . .5)$.

$\mathrm{e}_{\mathrm{ij}}=$ The random error term.

The Significant differences among treatment means were separated at alpha level $(\mathrm{P} \leq 0.05)$ by Duncan's multiple range test (1955).

\section{RESULTS AND DISCUSSION}

\section{Chemical composition:}

Data presented in Table (2) showed the chemical analysis of castor meal (CM), chemically treated castor meal (CTCM) and biologically treated castor meal (BTCM). Comparable to CM, CTCM and BTCM contained of CP (33.01 and 36.50 vs. 33.56\%), CF (12.28 and 9.90 vs. 12.65\%), EE (16.32 and 16.50 vs. $16.20 \%)$, NFE (24.98 and 25.09 vs. $28.48 \%)$ and DE (2547.39 and $2624.01 \mathrm{vs} .2535 .48 \mathrm{kcal} / \mathrm{kg})$. Biological treated caster meal tended to somewhat higher in CP content. On the contrary, CF content appended to lower with biological treatments being $9.90 \%$. In addition DE (kcal/ $\mathrm{kg}$ ) increased with BTCM recording $2624.01 \mathrm{kcal} / \mathrm{kg}$. The obtained results showed that chemical treatment was markedly affected approximate analysis of castor meal. Nitrogen free extract was markedly decreased while, CP content was slightly decreased, but ash content increased pronouncedly. The obtained results are in agreement with those reported by Diniz et al.(2010) who found that castor meal comparable to castor meal treated with calcium oxide, where CP (35.78 vs $34.44 \%)$, EE (17.1 vs $17.3 \%)$.

Table (2). Chemical analysis of castor meal (CM), chemically treated castor meal (CTCM) and biologically treated castor meal (BTCM) on DM\% basis.

\begin{tabular}{lccc}
\hline Items & CM & CTCM & BTCM \\
\hline DM\% & 90.40 & 91.20 & 90.12 \\
OM\% & 90.89 & 86.59 & 87.99 \\
CP\% & 33.56 & 33.01 & 36.50 \\
CF\% & 12.65 & 12.28 & 9.90 \\
EE\% & 16.20 & 16.32 & 16.50 \\
NFE\% & 28.48 & 24.98 & 25.09 \\
Ash\% & 9.11 & 13.41 & 12.01 \\
DE $(\mathrm{Kcal} / \mathrm{kg})^{*}$ & 2535.48 & 2547.39 & 2624.01 \\
\hline
\end{tabular}

$* D E(k c a l / k g)=4.36-0.049 x[28.924+0.657(C F \%)]$ according to Cheeke (1987).

The efficiency of the alkaline treatment is attributed to ricin denaturation by lime (Lehninger et al., 1995). Denaturation represents extreme alterations in the three-dimensional structure of a protein, which does not involve the breaking of peptide bonds and is almost always associated with loss of protein function (Lehninger et al., 1995). With alkaline treatment turning the protein net charge negative, provoking electrostatic repulsion and breaking the hydrogen bridges that support the three-dimensional structure (Oliveira, 2008). In addition to loss of function, hydrophobic groups are exposed during denaturation, resulting in decreased protein solubility in aqueous solutions. Therefore, the disappearance

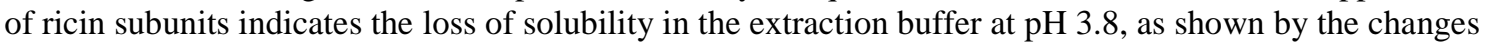
for the denatured state of the toxin when submitted to alkaline treatment $(60 \mathrm{~g}$ lime/ $\mathrm{kg}$ ) (Oliveira, 2008). Increasing ash content of CTCM may be due to increase minerals as calcium when treated with lime. Biological treatment had positive effects on improving the nutritive value of castor meal, since the protein contents was 
increased. This result confirmed by those of Villas-Boas et al. (2002) who reported that biological treatment is used for increasing the nutritional value of many by-products because they have significant concentrations of simple carbohydrates such as mono and disaccharides. While, crude fiber content was reduced because microorganisms depend on this material as carbon source for growth and formation the microbial protein. However, increasing ash content may be attributed to the growth or degradation of organic matter of castor bean meal by microorganism. Reduction in NFE may be related to the consumption of carbohydrates by the microorganism as energy sources for their growth and multiplication. These results are in good agreement with those reported by Abdel-Aziz et al. (2014) who found that biological treatments are paralleled with decreased crude fiber and fiber fractions content with increased crude protein content.

\section{Growth performance:}

Results of final body weight (FBW, g), body weight gain (BWG, g/ rabbit/ day), feed intake (FI, g/ rabbit/ day) and feed conversion ratio (FCR) are illustrated in Table (3). The FBW and BWG were insignificant $(\mathrm{P}>0.05)$ decreased for rabbits fed all experimental diets except those fed on $40 \%$ BTCM diet, there values were significantly $(\mathrm{P}<0.05)$ decreased when compared to those of control diet. The FBW values of tested diets were ranged from 1821.00 to $1900.00 \mathrm{~g}$ vs $2013.50 \mathrm{~g}$ for control one and the corresponding range for BWG was from 19.17 to $22.15 \mathrm{~g} v s 22.44 \mathrm{~g}$. Feed intake recorded the lowest value with rabbits fed $20 \%$ CTCM while, the highest value was occurred with rabbits fed on 40\% CTCM diet. Generally, most tested diets didn't affect FI significantly in comparison with control one. The best FCR was occurred with $20 \%$ CTCM diet, while the worst one was associated with 40\% CTCM diet and the differences among most treatments didn't significant. These results were agreement with Ani and Okorie (2002) who reported that when broilers fed 15\% cooking castor meal were reduced feed intake and weight gain. Adedeji et al. (2006) assessed the utilization of boiled castor seed cake in diet for weaned rabbits and observed a tolerant level not more than 15\%. Diniz et al. (2010) found that utilization of castor meal treated with lime solution in cattle diets at level 33 and 67\% substation of soybean meal didn't affect their daily weight gain. Moreover, Oso et al. (2011) stated that utilization of fermented castor meal in starting cockerels chicks diet at level $50 \mathrm{~g} / \mathrm{kg}$ diet didn't affect its growth response.

Table (3). Growth performance of growing rabbits fed on experimental diets.

\begin{tabular}{lllllll}
\hline \multirow{2}{*}{ Items } & \multirow{2}{*}{ Control } & \multicolumn{2}{c}{ CTCM } & \multicolumn{2}{c}{ BTCM } & \multirow{2}{*}{ SEM } \\
\cline { 3 - 6 } & & $20 \%$ & $40 \%$ & $20 \%$ & $40 \%$ & \\
\hline Initial body weight (IBW, g) & 756.67 & 776.67 & 736.67 & 733.00 & 747.67 & 6.99 \\
Final body weight (FBW, g) & $2013.50^{\mathrm{a}}$ & $1983.17^{\mathrm{a}}$ & $1900.0^{\mathrm{ab}}$ & $1974.00^{\mathrm{a}}$ & $1821.00^{\mathrm{b}}$ & 24.19 \\
Body weight gain (BWG, g/ R/ d ) & $22.44^{\mathrm{a}}$ & $21.54^{\mathrm{a}}$ & $20.77^{\mathrm{ab}}$ & $22.16^{\mathrm{a}}$ & $19.17^{\mathrm{b}}$ & 0.39 \\
Feed intake (FI, g/ R/ d) & $94.40^{\mathrm{ab}}$ & $80.99^{\mathrm{b}}$ & $97.55^{\mathrm{a}}$ & $89.99^{\mathrm{ab}}$ & $86.55^{\mathrm{ab}}$ & 2.21 \\
Feed conversion ratio (g feed/g gain) & $4.20^{\mathrm{ab}}$ & $3.75^{\mathrm{b}}$ & $4.69^{\mathrm{a}}$ & $4.06^{\mathrm{ab}}$ & $4.51^{\mathrm{ab}}$ & 0.14 \\
\hline
\end{tabular}

$a$ and $b$ means in the same row with different superscripts are significantly different $(P<0.05)$.

\section{Nutrients digestibility:}

The digestion coefficients of the experimental diets of the growing rabbits are shown in Table (4). These results indicated that insignificantly differences in DM and OM digestibilities among different diets. There were insignificantly decreased for digestion coefficients of CP, CF and NFE when rabbits fed diets containing CTCM and BTCM at levels $20 \%$ except for EE digestibility which had significantly $(\mathrm{P}<0.05)$ decreased with rabbits fed 20\% CTCM when compared to control group. Digestion coefficients of CP, CF and EE were insignificant decreased with rabbits fed diets containing 40\% CTCM compared to those fed on control diets. Nevertheless, NFE digestibility significantly $(\mathrm{P}<0.05)$ decreased with rabbits fed $40 \%$ CTCM when compared to control group. Digestion coefficient values of CP, CF, EE and NFE\% were significantly $(\mathrm{P}<0.05)$ decreased with rabbits fed diets containing 40\% BTCM when compared to control group. In this respect, Cobianchi et al. (2012) found that the digestibility coefficients of DM, OM and CP were not affected when replacing up to $67 \%$ of soybean meal by castor meal treated with calcium oxide in ration of dairy cows expect digestibility coefficient of $\mathrm{EE}$ which was reduced $(\mathrm{P}<0.05)$. On the other hand, Oso et al., (2011) stated that utilization of fermented castor meal in starting cockerels chick diets at levels 5, 10 and $15 \%$ had no effect on EE digestibility while increased CF digestibility. Whereas DM and CP digestibility were reduced with increasing fermented castor meal in the diet compared to those the control group. 
Table (4). Digestion coefficients of experimental diets.

\begin{tabular}{lllllll}
\hline \multirow{2}{*}{ Items } & \multirow{2}{*}{ Control } & \multicolumn{3}{c}{ CTCM } & \multicolumn{3}{c}{ BTCM } & \multirow{2}{*}{ SEM } \\
\cline { 3 - 6 } & & $20 \%$ & $40 \%$ & $20 \%$ & $40 \%$ & 1.38 \\
DM \% & 68.07 & 61.84 & 68.07 & 64.61 & 67.61 & 1.39 \\
OM \% & 70.64 & 63.96 & 64.30 & 71.75 & 71.59 & 0.72 \\
CP \% & $76.56^{\mathrm{a}}$ & $75.72^{\mathrm{a}}$ & $74.05^{\mathrm{ab}}$ & $75.23^{\mathrm{a}}$ & $70.56^{\mathrm{b}}$ & 2.71 \\
$\mathrm{CF} \%$ & $36.95^{\mathrm{a}}$ & $32.38^{\mathrm{ab}}$ & $29.63^{\mathrm{ab}}$ & $31.69^{\mathrm{ab}}$ & $26.96^{\mathrm{b}}$ & 1.58 \\
EE \% & $74.92^{\mathrm{a}}$ & $67.06^{\mathrm{bc}}$ & $72.35^{\mathrm{ab}}$ & $69.93^{\mathrm{a}}$ & $62.73^{\mathrm{c}}$ & 0.90 \\
NFE \% & $76.06^{\mathrm{a}}$ & $74.12^{\mathrm{ab}}$ & $72.34^{\mathrm{bc}}$ & $75.12^{\mathrm{ab}}$ & $69.87^{\mathrm{c}}$ & $0.05)$. \\
\hline
\end{tabular}

$a, b$ and $c$ means in the same row with different superscripts are significantly different $(P \leq 0.05)$.

\section{Nutritive value and nitrogen balance:}

Data concerning the nutritive value and nitrogen balance (NB) of the experimental diets of the growing rabbits are listed in Table (5). These results showed that digestible crude protein (DCP), total digestible nutrients (TDN) and digestible energy (DE) were significant lower with 40\% BTCM diet than control one, while the other tested diets mostly didn't significant differ in these parameters than control group. Comparatively, Cobianchi et al. (2012) found that TDN was insignificantly decreased at level of 33\% replacement of soybean meal by chemically treated castor meal, while it was reduced $(\mathrm{P}<0.05)$ at $67 \%$ replacement in cow diets. Moreover, Oliveira et al. (2010) indicated that the decrease in CP digestibility was probably due to the decrease in CP intake, which increase the participation of the fecal metabolic fraction.

As shown in Table (5), the results indicated that there was insignificant decrease in NB when rabbits fed on diets containing CTCM and BTCM at levels 20 and 40\% compared to the rabbits fed on the control diet. These results are in agreement with those reported by Cobianchi et al. (2012) who found that the nitrogen balance was not affected by chemically treated castor $(\mathrm{P}>0.05)$ up to $67 \%$ replacement of soybean meal in dairy cow diets, indicating that nitrogen intake meet the nitrogen requirement of cows.

In general, the improvement of digestibility of all nutrients, nutritive value, FBW and daily BWG in rabbits fed diets containing CTCM comparable to those of rabbits fed diets containing BTCM may be due to the more efficiency of chemical treatment than biological treatment respecting to reduced toxicity level of the castor meal. Oliveira et al. (2007) stated that treatment with calcium oxide or calcium hydroxide $(60 \mathrm{~g} / \mathrm{kg}$ castor meal) completely removed ricin from castor meal. Moreover, Diniz et al., (2010) found that using lime treatment (calcium oxide) (60g / kg castor meal) reduced ricin by $96.6 \%$. While, Godoy et al. (2009) found that using certain fungi such as Penicillium simplicissimum reduced ricin by only $16 \%$. However, the reduction of all nutrients digestibility, nutritive value, FBW and daily BWG in rabbits fed 40\% BTCM may be due to the increase of residual effects of castor allergen in castor meal which increased with increasing the level of BTCM in the diet. These results are in agreement with those reported with Oso et al. (2011) who stated that final live weight and average weight gain of the chicks reduced $(\mathrm{P}<0.05)$ with increasing dietary level of fermented castor meal in the diet.

Table (5). Nutritive value and nitrogen balance of experimental diets.

\begin{tabular}{lllllll}
\hline \multirow{2}{*}{ Items } & \multirow{2}{*}{ Control } & \multicolumn{3}{c}{ CTCM } & \multicolumn{3}{c}{ BTCM } & \multirow{2}{*}{ SEM } \\
\cline { 3 - 6 } & & $20 \%$ & $40 \%$ & $20 \%$ & $40 \%$ & \\
\hline DCP \% & $12.81^{\mathrm{a}}$ & $12.48^{\mathrm{a}}$ & $12.13^{\mathrm{ab}}$ & $12.55^{\mathrm{a}}$ & $11.75^{\mathrm{b}}$ & 0.12 \\
TDN\% & $65.75^{\mathrm{a}}$ & $62.92^{\mathrm{ab}}$ & $56.28^{\mathrm{b}}$ & $59.89^{\mathrm{ab}}$ & $55.33^{\mathrm{b}}$ & 1.34 \\
DE kcal/ kg* & $2913.3^{\mathrm{a}}$ & $2787.7^{\mathrm{ab}}$ & $2493.3^{\mathrm{b}}$ & $2653.6^{\mathrm{ab}}$ & $2451.1^{\mathrm{b}}$ & 58.92 \\
NB \% & 67.98 & 66.55 & 64.05 & 63.08 & 63.07 & 0.87 \\
\hline
\end{tabular}

$D E=T D N X 44.3$ according to (Schneider and flatt, 1975).

$a$ and $b$ means in the same row with different superscripts are significantly different $(P<0.05)$.

\section{Blood plasma constituents:}

The plasma concentration values of total protein, albumin, globulin, cholesterol, total lipid, urea, creatinine, alanine aminotransferase (ALT) and aspartate aminotransferase (AST) are shown in Table (6). The obtained values of those parameters were within the normal range. It could be noticed insignificantly differences in concentration of plasma total protein, albumin, globulin, cholesterol, total lipid, creatinine, ALT and AST of 
plasma for rabbits fed different tested treatments. However, urea was significantly increased with rabbits fed diets containing of CTCM and BTCM at level 40\% compared to those fed on control diet. Oso et al. (2011) stated that the utilization of fermented castor meal in starting cockerels chicks diet were not effected on total protein, albumin, globulin and uric acid. However, creatinine was significantly increased when dietary level of fermented castor meal increased in the diet. These results somewhat are in agreement with those obtained by Cobianchi et al. (2012) who found that the AST, ALT and urea concentration were insignificant differences among dairy cows fed on castor meal treated by calcium oxide up to $33 \%$ replacement of soybean meal.

\section{Economic efficienc:y:}

Profitability of using chemically and biologically castor meal in growing rabbit diets depended on feed cost and growth performance (Table 7). The lowest total feed cost / rabbit (12.78 LE) was observed with rabbits fed the diets containing 20\% CTCM followed by those fed 40\% BTCM (13.48 LE). While, groups fed the diets containing CTCM and BTCM at level $20 \%$ were achieved the highest economic efficiency (2.77 and 2.48) and relative economic efficiency (122.02 and 109.25) followed by a decreasing order by groups fed control diet or 40\% BTCM (95.59) and the least one was the group fed 40\%CTCM (91.62). Generally, it can be noticed that rabbits fed on the diets containing CTCM and BTCM at level $20 \%$ had the best economic return with compared to the other treatments.

It could be concluded that the chemically and biologically treated castor meal can be used in growing rabbit diets up to $20 \%$ as replacing of soybean meal without any adverse effect on growth performance of rabbits and healthy condition as well as its beneficial effect on feed cost and economical efficiency. Chemical treatment is more efficiency than biological treatment in respect of reducing the toxicity level of castor meal.

Table (6). Some blood constituents of growing rabbits fed on experimental diets.

\begin{tabular}{|c|c|c|c|c|c|c|c|}
\hline \multirow{2}{*}{ Items } & \multirow{2}{*}{$\begin{array}{c}\text { Normal } \\
\text { range }\end{array}$} & \multirow{2}{*}{ Control } & \multicolumn{2}{|c|}{ CTCM } & \multicolumn{2}{|c|}{ BTCM } & \multirow{2}{*}{ SEM } \\
\hline & & & $20 \%$ & $40 \%$ & $20 \%$ & $40 \%$ & \\
\hline Total protein, g/ dl & $5.5-6.5$ & 6.37 & 6.25 & 6.20 & 6.12 & 6.11 & 0.046 \\
\hline Albumin, g/ dl & & 3.93 & 3.91 & 3.81 & 3.64 & 3.43 & 0.12 \\
\hline Globulin g/ dl & & 2.68 & 2.53 & 2.46 & 2.19 & 2.18 & 0.12 \\
\hline Cholesterol, mg/ dl & $10-80$ & 36.48 & 36.45 & 35.13 & 35.17 & 37.41 & 2.73 \\
\hline Total lipid mg/ dl & $150-400$ & 354.68 & 365.74 & 354.67 & 377.74 & 381.85 & 3.72 \\
\hline Urea-N, mg/ dl & $15-50$ & $23.01^{\mathrm{b}}$ & $25.17^{\mathrm{ab}}$ & $29.06^{\mathrm{a}}$ & $26.74^{\mathrm{ab}}$ & $30.41^{\mathrm{a}}$ & 0.39 \\
\hline Creatinine, $\mathrm{mg} / \mathrm{dl}$ & $0.5-2.6$ & 1.42 & 1.42 & 1.60 & 1.46 & 1.64 & 0.048 \\
\hline $\mathrm{AST}(\mathrm{U} / \mathrm{L})$ & $17-98$ & 26.33 & 25.00 & 23.66 & 23.33 & 28.10 & 0.78 \\
\hline $\operatorname{ALT}(\mathrm{U} / \mathrm{L})$ & $12-73$ & 15.33 & 16.33 & 17.33 & 15.33 & 14.67 & 0.61 \\
\hline
\end{tabular}

$a$, and $b$ means in the same row with different superscripts are significantly different $(P \leq 0.05)$.

Table (7). Economic efficiency of growing rabbits fed experimental diets.

\begin{tabular}{llllll}
\hline \multirow{2}{*}{ Items } & \multirow{2}{*}{ Control } & \multicolumn{2}{c}{ CTCM } & \multicolumn{2}{c}{ BTCM } \\
\cline { 3 - 6 } & & $20 \%$ & $40 \%$ & $20 \%$ & $40 \%$ \\
\hline Total average weight (kg) & 1.256 & 1.206 & 1.163 & 1.240 & 1.074 \\
Price of one kg body weight (LE) & 40 & 40 & 40 & 40 & 40 \\
Selling price/ rabbit (LE)(A) & 50.24 & 48.24 & 46.52 & 49.6 & 42.96 \\
Total feed intake & 5.27 & 4.53 & 5.46 & 5.03 & 4.85 \\
Price/ kg feed(LE) & 2.91 & 2.82 & 2.76 & 2.83 & 2.78 \\
Total feed cost/ rabbit (LE) B & 15.34 & 12.78 & 15.07 & 14.24 & 13.48 \\
Net revenue(LE) $^{1}$ & 34.90 & 35.45 & 31.45 & 35.36 & 29.48 \\
Economic efficiency $^{2}$ & 2.27 & 2.77 & 2.08 & 2.48 & 2.17 \\
Relative economic efficiency $^{3}$ & 100 & 122.0 & 91.62 & 109.25 & 95.59 \\
\hline
\end{tabular}

(1) Net revenue $=A-B$

(2) Economic efficiency $=(A-B / B)$

(3)Relative economic efficiency = Economic efficiency of treatments other than the control / Economic efficiency of the control group. 


\section{REFERENCES}

Abdel-Aziz Nahla, A.; Z.M.S. Abdelfattah; M.M. El-Adawy; L.M. Camacho; A.E. Kholif; Mona, M.Y. Elghandour and B.E. Borhami (2014). Biological Treatments and Feeding Sugarcane Bagasse in Agriculture Animals- An Overview. J. Integ. Agric. Adva. Online Publication. Doi: 10.1016/ S20953119(14)60829-7.

Adedeji, J.A.; D.F. Apata; O.A. Aderinola; T.A. Rafiu and S.R. Amao (2006). Performance and haematological/ serum characteristics of rabbits fed boiled castor seed cake based diet. World J. Zool., 1:91-93.

Aganga, A.A. and S.O. Tshwenyane (2003). Feeding values and anti-nutritive factors of forage tree legumes. Pak. J. Nut., 2:170-177.

Anandan, S.; G. Kumar; J. Ghosh and K. Ramachandra (2005). Effect of different physical and chemical treatments on detoxification of ricin in castor cake. Anim. Feed Sci. and Techn., 120:159-168.

Ani, A.O. and A.U. Okorie (2002). The nutritive value of dehulled and cooked castor oil bean (Ricinus communis L) meal to broiler finishers. Proc. Ann. Conf. of Nig. Soci. for Anim. Prod., 27:141-143.

A.O.A.C. (2000). Official Methods of Analysis. 17th ed., published by the A.O.A.C., Washington, D.C., USA.

Cheeke, P.R. (1987). Rabbit Feeding and Nutrition. Academic Press Orlando, Florida, USA, 376 p.

Cobianchi, J.V.; A.S. de Oliveira; J.M.S. Campos; A.V.S.Campos; S.C. Valadares Filho; F.C. Pereira and T.E.S. de Oliveir (2012). Productive performance and efficiency of utilization of the diet components in dairy cows fed castor meal treated with calcium oxide. Revista Brasileira de Zootecnia., 41:2238-2248.

Day, P.J.; T.J. Pinheriro; L.M. Roberts and J.M. Lord (2002). Binding of ricin A- chain to negatively charged phospholipids vesicles leads to protein structural changes and destabilizes the lipid bilayer. Biochemistry, 41:2836-2843.

Diniz, L.L.; S.C. Valadares Filho; J.M.S. Campos; R.F.D. Valadares; L.D. da Silva; J.P.I.S. Monnerat; P.B. Benedeti; A.S. de Oliveira and D.S. Pina (2010). Effect of castor meal on the growth performance and carcass characteristics of beef cattle. Asian Aust. J. Anim. Sci., 23:1308-1318.

Doumas, B.T. and W. Waston (1971). Albumin standards and measurement of plasma albumin with bromocresol green. Clin. Chem. Acta., 31:87.

Duncan, D.B. (1955). Multiple Range and Multiple F-Test. Biometrics, 11:1-42.

FAO (2013). Food and Agriculture Organization of the United Nations. http:/ / apps.Fao.org

Fawcett, J.K. and J.E. Scott (1960). Determination of urea. J Clic. Path., 13:156-159.

Fekete, S. (1985). Rabbit feeds and feeding with special regard to tropical condition. J. of Applied Rabbit Research, 8:167-173.

Godoy, M.G.; M.L.E. Gutarra; F.M. Maciel; S.P. Felix; J.V. Bevilaqua; O.L.T. Machado and D.M.G. Freire (2009). Use of a low-cost methodology for biodetoxification of castor bean waste and lipase production. Enzyme and microbial technology, 44:317-322.

Gornall, A.G.; C.J. Bardawill and M.M. Divid (1949). Determination of plasma protein by means of the biurent reaction. J. Biol.Chem., 177:751.

Lehninger, A. L.; D.L. Nelson and M.M. Cox (1995). Principles of Biochemistry, Worth Publishers, New York, NY, USA, 587 p.

Long, J.L. (2005). Gale Encyclopedia of alternative medicine.2nded.Castor oil; pp. 369-372.

NRC (1977). National Research Council. Nutrient requirements of rabbits. Nat. Acad. Sci., Washington, DC., USA.

Oliveira, A.S. (2008). Co-produtos da extração de óleos de sementes de mamona e de girassol na alimentação de ruminantes. Viçosa, MG, 2008. p. 165. Tese (Doutorado em Zootecnia), Universidade Federal de Viçosa (cited after Diniz et al., 2010).

Oliveira, A.S.; M.R.C. Oliveira and J.M.S. Campos (2007). Eficacia de diferentesmetodosdedestoxificaçao da ricina do farelo de mamona. In: II Congresso da RedeBrasileira de Tecnologia de Biodiesel, Brasilia. Anais. CD-ROM Brasilia: MCT/ ABIPTI, p.1-6. (cited after Diniz et al., 2010).

Oliveira, A.S.; J.M.S. Campos and M.R.C. Oliveira (2010). Nutrient digestibility, nitrogen metabolism and hepatic function of sheep fed diets containing solvent or expeller castor seed meal treated with calcium hydroxide. Anim. Feed Sci. and Techn., 158:15-28. 
Oso, A.O.; W.A. Olayemi; A.M. Bamgbose and O.F. Fowoyo (2011). Utilization of fermented castor oil seed (Ricinuscommunis, L.) meal in diets for cockerl chicks. Arch. Zootec., 60:75-82.

Richmond, W. (1973). Determination of cholesterol. Clin. Chem., 19:1350.

SAS (2004). User's guide. Statistic. SAS Inst. Cary, N.C. Releigh.

Schirmeister, J. (1964). Determination of creatinine. Dtsch. Med Wschr., 89:1940.

Schneider, B.H. and W.P. Flatt (1975). The Evaluation of Feed Through Digestibility Experiments. University of Georgia Press Athens, Georgia, USA.423p.

Severino, L.S. (2005). Oquesabemossobre a torta de mamona (In: Portuguese, What we know about the cake of castor), p. 31. (EmbrapaAlgodão. Documentos, 134).

Villas-Boas, S.G.; E. Esposito and D.A. Mitchell (2002). Microbial conversion of lignocellulosic residues for production of animal feeds. Anim. Feed Sci. and Techn., 98:1-2.

Young, D.S. (1990). Effects of drugs on clinical laboratory tests, 3:6-12.

Zollner, N. and K. Kirsch (1962). Determination of total lipids in blood by colorimetric method. Z. Ges. Exp. Med. 135:454-454. 


\title{
Suliman et al.
}

الأداء الانتاجي للارانب النيوزيلندي البيضاء الناميه المغذاه على علائق تحتوي على مستويات مختلفه من كسب

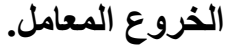

\author{
مروه عبد المنعم سليمان، ولاء عطيه سلامه ، رضا ابراهيم مطري، محمد احمد الشورى \\ معهل بحوث الاتتاج الحيوانسي، مركز البحوث الزراعيه، اللققي ، الجيزه، مصر.
}

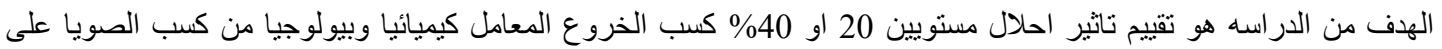

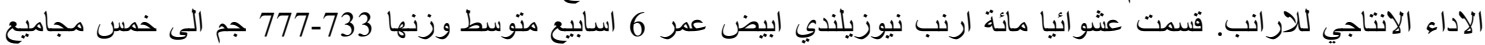

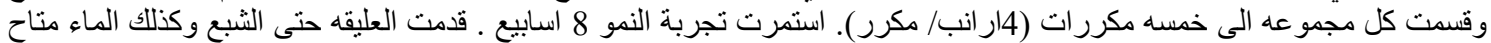

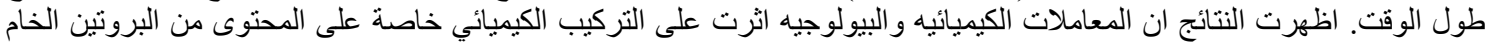

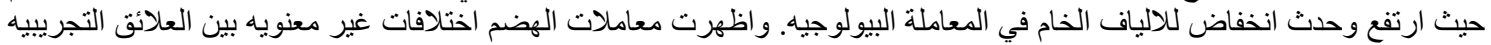

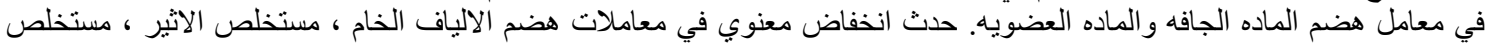

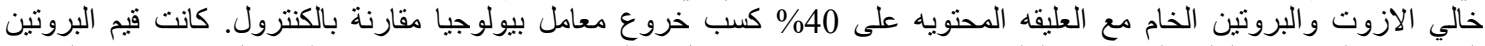

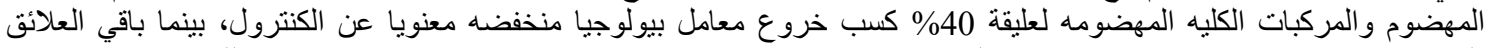

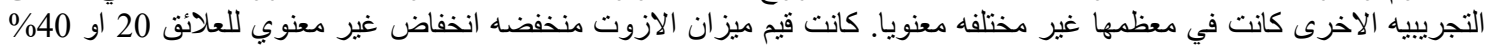

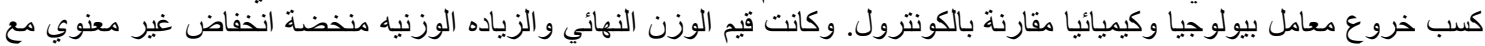

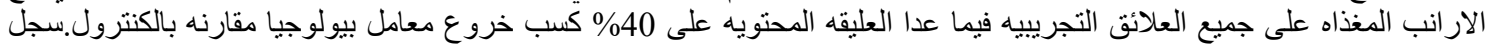

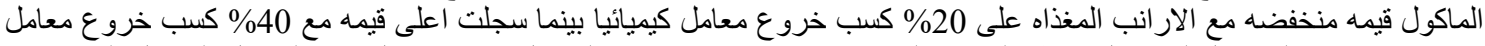

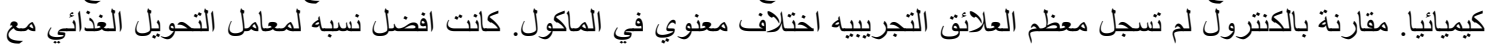

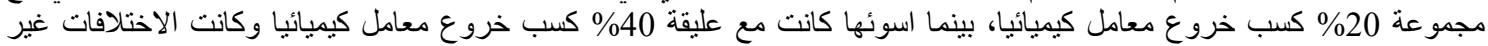

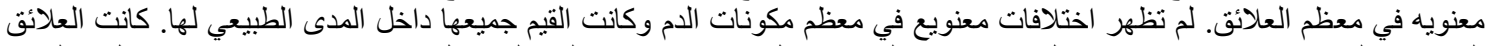

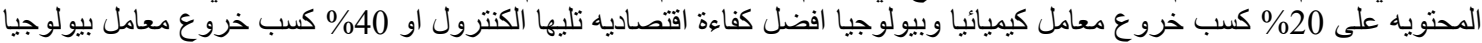

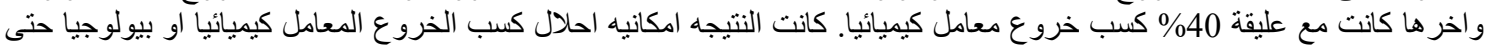
مستوى 20\% في علائق الار انب الناميه دون اي اثار سيئه على الاداء الانتاجي و الصحه. 